Environment, Biodiversity \& Soil Security
(EBSS)

\title{
Management of Greenhouse Cucumber Production under Arid Environments: A Review
}

\author{
Naglaa Taha ${ }^{1}$, Neama Abdalla ${ }^{2}$, Yousry Bayoumi ${ }^{3,4}$ and Hassan El-Ramady ${ }^{5^{*}}$ \\ ${ }^{1}$ Plant Pathology Research Institute, Agriculture Research Center, Sakha, Kafr El- \\ Sheikh, Egypt \\ ${ }^{2}$ Plant Biotechnology Dept., Genetic Engineering Division, National Research \\ Center, 33-El-Behouth Street, Giza, Egypt \\ ${ }^{3}$ Horticulture Dept., Faculty of Agriculture, Kafrelsheikh University, Egypt \\ ${ }^{4}$ Physiology \& Breeding of Horticultural Crops Laboratory, Horticulture Dept., \\ Faculty of Agriculture, Kafrelsheikh University, Egypt \\ ${ }^{5}$ Soil and Water Dept.Faculty of Agriculture, Kafrelsheikh University, Egypt
}

\begin{abstract}
REENHOUSE cucumber production is considered an important tool beside open field production. The production of greenhouse cucumber in developing countries particularlyinarid environments mightachieve as low cost structures and almost without air conditions. These conditions have increased the constrains of cucumber production to be include more stresses beside salinity, drought and heat stress. These stresses mainly include biotic stress and abiotic stresses, which cause a high loss in the cucumber productivity. Thus, this review is an attempt to highlight the problems of greenhouse cucumber production under abiotic stress (mainly drought and salinity) and different strategies, which should be adapted against these stresses. Several studies have handled the individual stresses, which impact on greenhouse cucumber production but fewer studies have investigated the multiple or combined stresses.Salinity and drought are most common abiotic stresses under changing climate, which mainly cause a trouble in cucumber antioxidant enzyme activity and generate an oxidative stress leading to a loss in cucumber productivity. New strategies should be adapted to ameliorate or mitigate the expected damage resulting from salinity and drought-stressed cucumber.
\end{abstract}

Keywords: Abiotic stress, Climate changes, Drought, Salinity, Heat stress.

\section{Introduction}

The production of vegetables particularly cucumber in greenhouses has become an important agricultural pattern all over the world because of the growing consumption rate of vegetables and the limiting cultivated lands (Liu et al., 2020c). The long-term intensive production of greenhouse cucumber may create ecological problems due to the imbalance in soil microbial communities, increasing soil borne diseases and soil salinization, which might decline this cucumber productivity under greenhouses (Xiao et al., 2019). Therefore, the protected production of cucumber should be managed for more environmental health with a balance between the productivity and the profitability (Ali et al., 2019 a, b; Abdalla et al., 2020). This management should not only depend on the traditional agro-ecological practices but also mightconsider the plant biodiversity, soil quality and crop productivityor sustainable practices of the agriculture (El-Ramady et al., $2019 \& 2020$ and Zhao et al., 2020). The problems of cucumber production under greenhouses in developing countries during summer season (May to August) in arid zones is representing a crucial challenge how to avoid heat stress in particular the un air-conditional greenhouses.

${ }^{*}$ Corresponding author : E-mail:hassan.elramady@agr.kfs.edu.eg

Authors Emails: ('nagla abdelbaset@yahoo.com),

( ${ }^{2}$ : neama ncr@yahoo.com), ( ${ }^{3}$ :ybayoumi2002@yahoo.com.sg)

Received: 20/05/ 2020 ; Accepted:27/06/ 2020

DOI: $10.21608 /$ jenvbs.2020.30729.1097

(C)2020 National Information and Documentation Center (NIDOC) 
Cucumber (Cucumis sativus L.) is a widely cultivated vegetable crop grown in open fields and greenhouses, which belongs to the family Cucurbitaceae.The global ranking of cucumber production is following after potato, tomato and onion. The production of greenhouse cucumber is perceived as an economically important cash crop and the cultivated area is increasing worldwide (Ali et al., 2019b). High cucumber productivity has been achieved in the past decades due to the intensive input of irrigation water and mineral fertilizer particularly nitrogen causing serious environmental problems (Sun et al., 2019). These problems could be managed through the following approaches reducing reactive $\mathrm{N}$-gases emissions, mitigating $\mathrm{N}$-losses mainly leaching of nitrate to secure water quality, and enhancing the efficiency of resources to reduce the costs and to create higher values (Sun et al., 2019 and Cui et al., 2020).

Therefore, this review is an attempt to highlight the management of greenhouse cucumber under changing environments, which have serious impacts on cucumber productivity in the era of climate changes. The greenhouse cucumber production underabiotic stress will be mainly discussed.

\section{Obstacles of Greenhouse Cucumber Production}

The production of greenhouse vegetables like cucumber has developed rapidly in recent years. This production has become an effective tool in producing cucumber due to very high controllability as "high technology structures"in the developed countries (Dong et al., 2020a). It could be partially modifiedthe climatic parameters mainly temperature and humidity to develop the growing system in greenhouse under adverse conditions (Phogat et al., 2020). In the developing countries, fewer facilitiesare availableas "low cost structures" creating many stressful conditions in greenhouse cucumber production (Fig. 1 and 2). High-tech greenhouses, which use soilless growing media, are more expensive (5 to 10 times) thanlow cost soil-based greenhouses (Phogat et al., 2020). The main problems facing the greenhouse cucumberproduction may include soil salinization and degradation, nitrate groundwater pollution and heat stress (Cui et al., 2020). These problems have been become major obstacles in greenhousecucumber productionparticularly under changing climate. Climate change mayinclude the elevated $\mathrm{CO}_{2}$, high temperatures, increased frequency of extreme temperatures andchanged rainfall patterns (Dong et al. 2020a). Atmospheric greenhouse gases (GHG) including $\mathrm{N}_{2} \mathrm{O}, \mathrm{CO}_{2}$, and $\mathrm{CH}_{4}$ have increased by 20,41 and $160 \%$, respectively, compared with those before industrial revolution (Shen et al., 2020). The agricultural production may share in these GHG with $9-14 \%$ of global net $\mathrm{CO}_{2}$ emissions (Zarei et al., 2019). It was found that elevated CO2 (550 $\mu \mathrm{mol} \mathrm{mol}{ }^{-1}$ ) increased the cucumber fruit yield by 33\% (Dong et al., 2020a), whereas theelevated $\mathrm{CO}_{2}\left(1200 \mu \mathrm{mol} \mathrm{mol}{ }^{-1}\right)$ decreased N-uptake efficiency of cucumber roots and decreased the $\mathrm{NH}_{4}^{+}$oxidation and denitrification (Dong et al., 2020b).

The production of cucumber under greenhouse in low cost structure has many problems including energy efficient (Iddio et al., 2020), greenhouse soil degradation due to the intensive applications of fungicides (Zhang et al., 2020), soil salinization (Phogat et al., 2020), soil nutrient imbalance (Fan et al., 2020), and deterioration of soil microbial communities (Liu et al., 2020c and Zhao et al., 2020). The long-term production of greenhouse cucumber may cause a lot of problems in the structure of soil microbial community (Liu et al., 2020c). All natural resources should be sustainably managed including the energy (Taki \& Yildizhan 2018 and Asgharipour et al., 2020), water conservation (Liang et al. 2018; Sun et al. 2019) and soil and protecting from pollution and degradation (Zhao et al., 2020).

Plant pathogens (i.e., bacteria,fungi, viruses and nematodes) of greenhouse cucumber are considered one ofthe main limiting factorsduring greenhouse cucumber production (Punja et al., 2019). There are several common phyto-pathogens and diseases, which can cause damage and decline in the yield of greenhouse cucumber such as fusarium wilt, powdery mildew, downy mildew and Alternaria blight (Punja et al., 2019). The most common fungal pathogens may include fusarium wilt (Fusarium oxysporum), Pythium crown and root rot (Pythium aphanidermatum), gummy stem blight (Didymella bryoniae), Botrytis grey mould (Botrytis cinerea), and powdery mildew (Podosphaera xanthii) (Punja et al. 2019). A part from pesticides, there are many other chemical and biological agents or nutrients could be applied for greenhouse cucumber control such as foliar manganese on Colletotrichum lagenarium (Eskandari et al., 2020) or on powdery mildew (Eskandari and Sharifnabi 2019), applied Bacillus subtilis against some fungal pathogens (Punja et al., 2019), applied NiOnano-particles against cucumber mosaic virus (Derbalah and Elsharkawy, 2019) and applied some nano-molecules against powdery mildew (Hafez et al., 2020). 

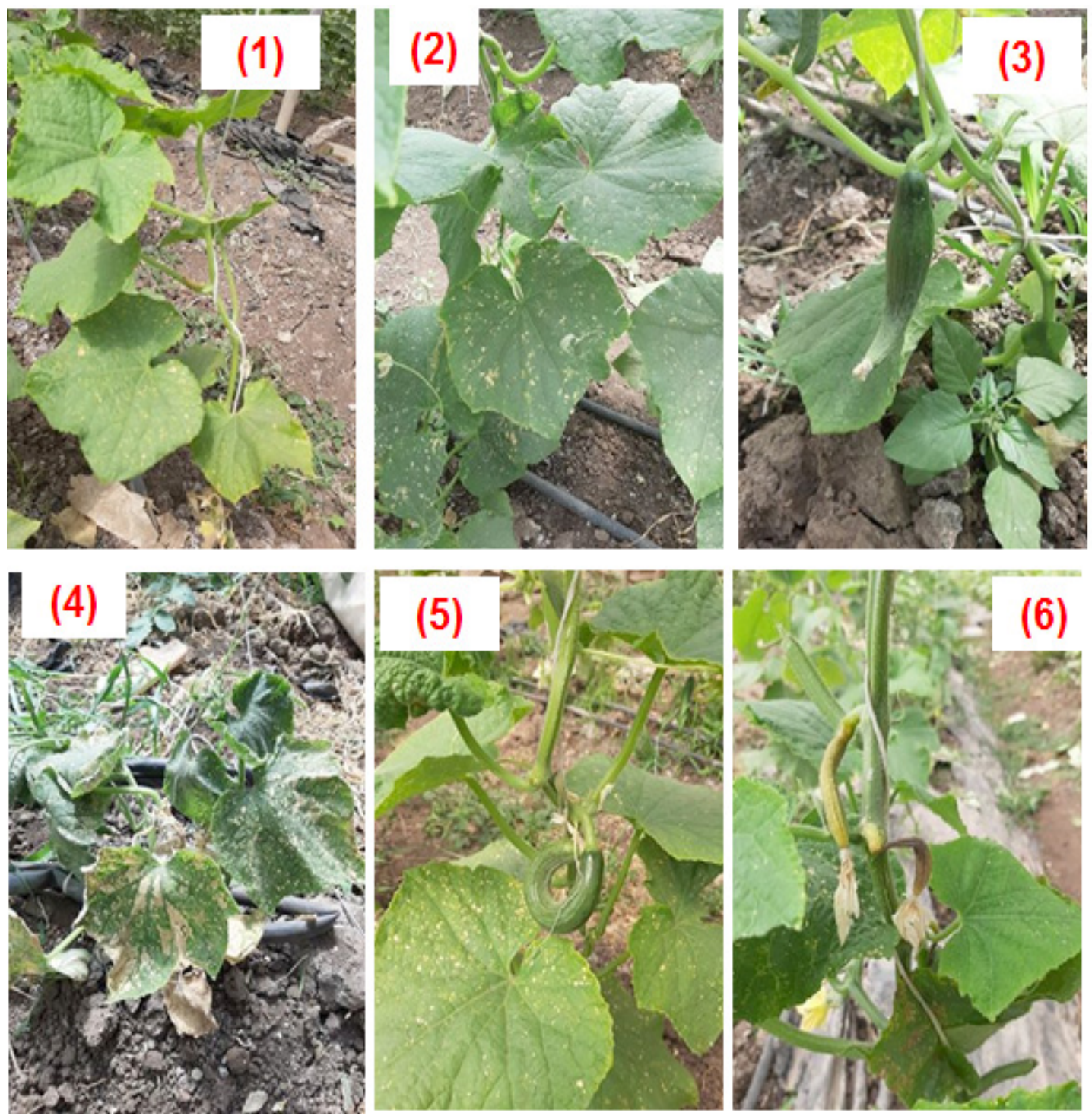

Fig. 1. Cucumber production under greenhouse conditions faces many abiotic stresses such as general yellowing (photo 1), heat stress (photo 2), Ca-deficiency (photo 3), multi-stresses (photo 4), curly cucumber fruits due to $\mathrm{N}$ - deficiency (photo 5), and abortion fruits (photo 6)(all photos by authors)

The biocontrol agents (BCAs) or biological control (e.g., Trichoderma) is an important strategy could be applied in control phyto-pathogens of greenhouse cucumber (Zhang and Zhuang, 2020). More than 260 species of Trichoderma have been identified, which include about 35 established species as economic biocontrol agents due to their producing antibiotics and enzymes (Sharma et al., 2019). Due to the importance of Trichoderma, several studies have handled these useful strains, which control phyto-pathogenic fungi through their high survival under stressful conditions, high efficiency in nutrients utilization, degradation the cell walls of pathogen by secreted enzymes, and producing active antimicrobial compounds (Zhang and Zhuang, 2020). The most important strains of Trichoderma, which already published in many studies included applied $T$. atroviride to reduce downy mildew (Szczech et al., 2017), T. asperellumto prevent cucumber fusarium wilt (Li et al., 2019b),T. pseudokoningii to control cucumber fusarium wilt (Cong et al., 2019), T. brevicrassum to diminish cucumber disease of Rhizoctonia solani (Zhang and Zhuang, 2020). These Trichoderma strains also enhanced tolerance of cultivated cucumber to abiotic stress (Kashyap et al., 2017) such as T. harzianum, which mitigates the salinity stress (Zhang et al., 2019). 

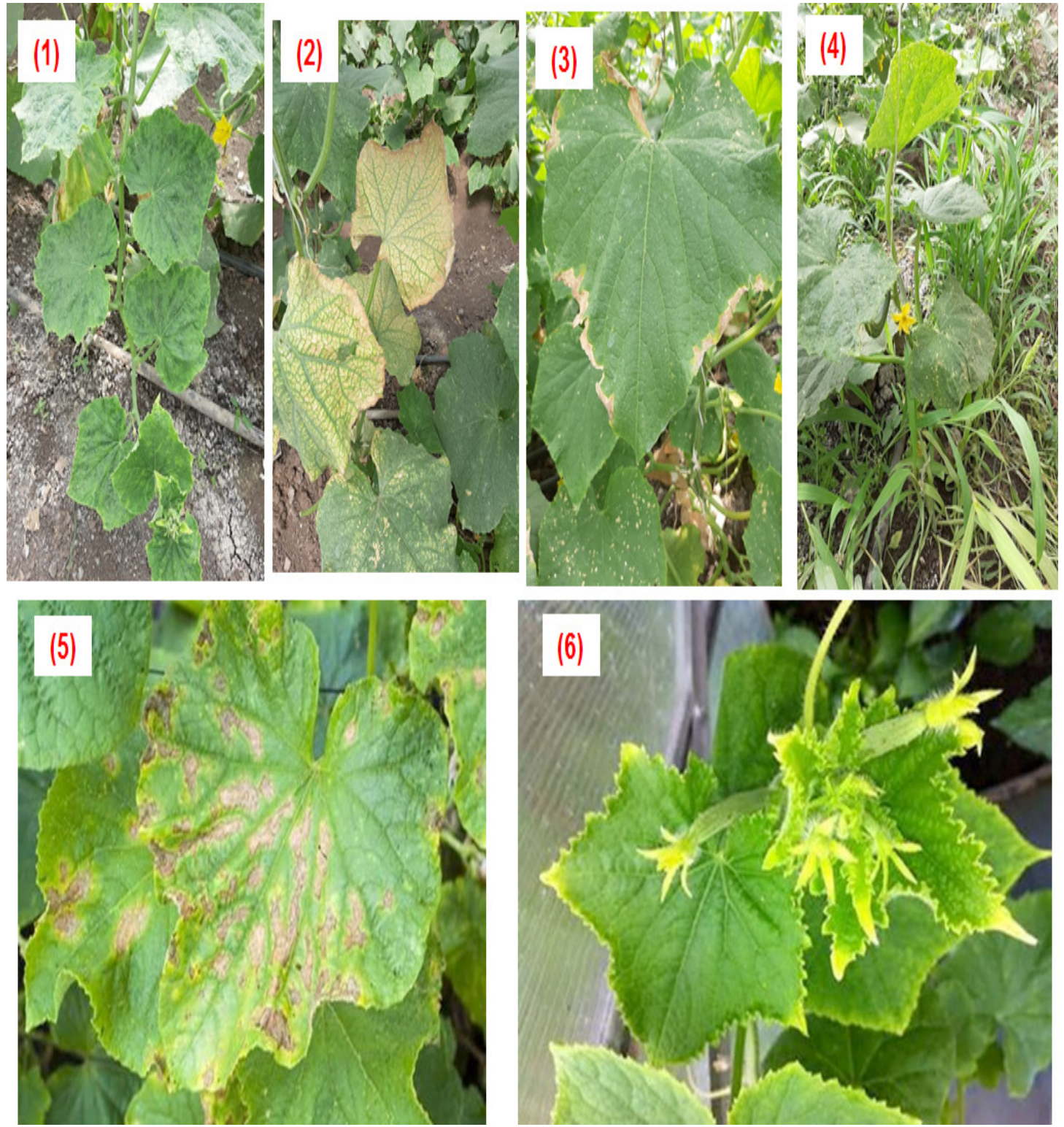

Fig. 2. More stresses on cucumber grown in greenhouse conditions:virus disease (photo 1), multiple stresses (photo 2), salinity stress (photo 3), weed stress (photo 4), downy mildew disease (photo 5), andK-deficiency (photo 6) (all photos by authors)

\section{Greenhouse Cucumber Production under Abiotic Stress}

The production of greenhouse cucumber has a lot of constraints limiting the growth and development of cultivated plants. These constrains include biotic and abiotic stresses, which have been handled in several investigations (Tables 1 and 2). These studies mainly focused on different stresses as an individual case and a fewer cases as multiple stresses (e.g., Liu et al. 2018). The behavior of cultivated cucumber towards these stresses and their mechanisms also has been reported andhow these plantsadapt their selves to be more tolerant tostress or through application of many anti-stress materials and nutrients. Under abiotic stress, cucumber plants suffer from the accumulation of large amounts of mis-folded or unfolded proteins in plant cells (Hou et al. 2020). The mode of actions including amelioration, mitigation, and compensation of greenhouse cucumber towards the negative effects of stress on plant growth also has listed in Tables 1 and 2. 
TABLE 1. Response of cucumber plants to various abiotic stresses in some published articles during 2019

\begin{tabular}{|c|c|c|c|}
\hline Growth details & Stress details & Response & Reference \\
\hline $\begin{array}{l}\text { At 3-leaf-stage } \\
\text { treated } 100 \mu \mathrm{M} \\
\text { NaHS }\end{array}$ & $\begin{array}{l}\text { Nitrate stress } \\
(140 \mathrm{mM})\end{array}$ & $\begin{array}{l}\mathrm{H}_{2} \mathrm{~S} \text { has a protective role under nitrate stress } \\
\text { by regulating antioxidant enzyme activities }\end{array}$ & Qi et al. (2019) \\
\hline $\begin{array}{l}\text { Soil amended }(100 \\
\left.\mathrm{mg} \mathrm{kg}^{-1}\right) \mathrm{NMs} \\
\left(\mathrm{SiO}_{2}, \mathrm{TiO}_{2}, \mathrm{ZnS} \mathrm{\&}\right. \\
\left.\mathrm{MoS}_{2}\right)\end{array}$ & $\begin{array}{l}\text { Heavy metals } \\
\text { stress: } \mathrm{As}, \mathrm{Pb} \text { and } \mathrm{Cd} \\
\quad(65.2,182 \text { and } \\
\left(3.52 \mathrm{mg} \mathrm{kg}^{-1} \text {, resp.) }\right.\end{array}$ & $\begin{array}{l}\text { Studied nanomaterials (NMs) showed great } \\
\text { potential in reducing uptake of } \mathrm{As}, \mathrm{Cd}, \mathrm{Cr} \text {, } \\
\mathrm{Cu}, \mathrm{Ni}, \mathrm{Al} \text { and } \mathrm{Pb} \text { in roots particularly } \mathrm{MoS}_{2} \\
\mathrm{NMs} \text { in Soil Cultivated Cucumber Plants }\end{array}$ & Song et al. (2019) \\
\hline 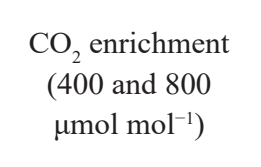 & $\begin{array}{l}\text { Drought stress via } \\
\text { polyethylene glycol: } 5 \\
\text { and } 10 \%\end{array}$ & $\begin{array}{l}\mathrm{CO}_{2} \text { enrichment enhanced efficiency of } \\
\text { photosynthetic electron transport; alleviated } \\
\text { under drought stress toxic substances } \\
\text { accumulation }\end{array}$ & Cui et al. (2019) \\
\hline $\begin{array}{l}\text { Nano-silica }(400 \\
\left.\quad \mathrm{mg} \mathrm{kg}^{-1}\right)\end{array}$ & $\begin{array}{l}\text { Water deficit }(70 \% \text { of } \\
\left.\text { ET }_{c}\right) ; \text { saline irrigation } \\
\text { water }\left(1.7 \mathrm{dS} \mathrm{m}^{-1}\right)\end{array}$ & $\begin{array}{l}\text { Nano-silica maintain ion homeostasis, } \\
\text { regulate osmotic balance and control opening } \\
\text { of stomata }\end{array}$ & $\begin{array}{l}\text { Alsaeedi et al. } \\
(2019)\end{array}$ \\
\hline $\begin{array}{l}\text { Soils treated with } \\
5 \& 10 \% \text { industrial } \\
\text { solid wastes }\end{array}$ & $\begin{array}{l}\text { Saline irrigation water } \\
\qquad\left(4 \text { and } 8 \mathrm{dS} \mathrm{m}^{-1}\right)\end{array}$ & $\begin{array}{l}\text { Salinity decreased } \mathrm{Zn} \text {-content and its uptake; } \\
\text { increased the uptake of } \mathrm{Cd}, \mathrm{Cr}, \mathrm{Cu}, \mathrm{Ni}, \mathrm{Pb} \text { by } \\
\text { all parts of the plants }\end{array}$ & $\begin{array}{l}\text { Taghipour and } \\
\text { Jalali (2019). }\end{array}$ \\
\hline $\begin{array}{l}4 \text { commercial } \\
\text { rootstocks were } \\
\text { investigated }\end{array}$ & $\begin{array}{l}\text { Salinity stress } \\
\text { (up to } 7.5 \mathrm{dS} \mathrm{m}^{-1} \text { ) }\end{array}$ & $\begin{array}{l}\text { Grafted rootstock tolerant to salinity can } \\
\text { decrease } \mathrm{Ca}^{++} \text {and } \mathrm{K}^{+} / \mathrm{Na}^{+} \text {ratio in leaves, with } \\
\text { high } \mathrm{Na}^{+} \text {and } \mathrm{Cl}^{-} \text {content }\end{array}$ & $\begin{array}{l}\text { Usanmaz and } \\
\text { Abak (2019) }\end{array}$ \\
\hline $\begin{array}{l}\text { Applied N-rate up } \\
\text { to about } 500 \mathrm{~kg} \mathrm{~N} \\
\mathrm{ha}^{-1}\end{array}$ & $\begin{array}{l}\text { Water table stress } \\
\text { (ranged } 10-77 \mathrm{~cm})\end{array}$ & $\begin{array}{l}\text { Under high water table, } 75 \% \text { of the } \\
\text { recommended } \mathrm{N} \text { rate could optimize } \\
\text { cucumber yield via drip fertigation }\end{array}$ & Wang et al. (2019) \\
\hline $\begin{array}{l}\mathrm{CO}_{2} \text { enrichment } \\
(400 \text { and } 800 \\
\left.\mu \mathrm{mol} \mathrm{mol}^{-1}\right)\end{array}$ & $\begin{array}{c}\text { Salt stress } \\
\left(80 \mathrm{mmol} \mathrm{L}^{-1} \mathrm{NaCl}\right)\end{array}$ & $\begin{array}{l}\text { Enriched } \mathrm{CO}_{2} \text { promoted } \mathrm{K}^{+} \text {accumulation in } \\
\text { plants; reduced the } \mathrm{Na}^{+} / \mathrm{K}^{+} \text {ratio; maintained } \\
\text { ion balance in plants under stress }\end{array}$ & Li et al. (2019a) \\
\hline $\begin{array}{c}\text { Foliar applied } \\
\text { putrescine }(8 \mathrm{mM})\end{array}$ & $\begin{array}{c}\text { Salt stress } \\
(75 \mathrm{mM} \mathrm{NaCl})\end{array}$ & $\begin{array}{l}\text { Putrescine alleviated starch over- } \\
\text { accumulation in leaves; protecting } \\
\text { photosynthetic organs; enhancing seedling } \\
\text { tolerance to salt stress }\end{array}$ & Shen et al. (2019) \\
\hline $\begin{array}{c}\text { Foliar applied } \\
\text { putrescine }(8 \mathrm{mM})\end{array}$ & $\begin{array}{c}\text { Salt stress } \\
(75 \mathrm{mM} \mathrm{NaCl})\end{array}$ & $\begin{array}{l}\text { Putrescine may improve photochemical } \\
\text { efficiency in salt stress by increasing } \\
\text { polyamines to alter the adaptation of LHCII }\end{array}$ & Shu et al. (2019) \\
\hline $\begin{array}{l}\text { Putrescine }(0.8 \\
\mathrm{mM})\end{array}$ & $\begin{array}{c}\text { Salt stress } \\
(75 \mathrm{mM} \mathrm{NaCl})\end{array}$ & $\begin{array}{l}\text { Putrescine regulates ion balance in } \mathrm{NaCl}- \\
\text { stressed cucumber }\end{array}$ & Yuan et al. (2019) \\
\hline Putrescine (8 mM) & $\begin{array}{c}\text { Salt stress } \\
(90 \mathrm{mM} \mathrm{NaCl})\end{array}$ & $\begin{array}{l}\text { Exogenous putrescine alleviated photo- } \\
\text { inhibition caused by salt stress }\end{array}$ & Wu et al. (2019a) \\
\hline $\begin{array}{l}\text { Silicon } 0.3 \mathrm{mM} \\
\text { added as sodium } \\
\text { silicate }\end{array}$ & $\begin{array}{c}\text { Salt stress } \\
(75 \mathrm{mM} \mathrm{NaCl})\end{array}$ & $\begin{array}{l}\text { Si can enhance salt-tolerance of cucumber } \\
\text { by increasing accumulation of polyamine; } \\
\text { decreasing oxidative damage }\end{array}$ & Yin et al. (2019) \\
\hline $\begin{array}{l}\text { Seedlings treated } \\
\text { with } \mathrm{Si}(0.3 \mathrm{mM})\end{array}$ & $\begin{array}{c}\text { Salt stress } \\
(75 \mathrm{mM} \mathrm{NaCl})\end{array}$ & $\begin{array}{l}\text { Silicon may increase tolerance the crop } \\
\text { production in saline soils }\end{array}$ & Zhu et al. (2019) \\
\hline
\end{tabular}


TABLE 2. Response of cucumber plants to various abiotic stresses in some published articles during 2020

\begin{tabular}{|c|c|c|c|}
\hline Growth details & Stress details & Response & Reference \\
\hline $\begin{array}{l}\text { Foliar Si }(1.5 \mathrm{mM}) \text {, } \\
\text { harvested at } 2^{\text {nd }} \text { leaf }\end{array}$ & $\begin{array}{l}\text { Nitrate stress } 200 \mathrm{mM} \\
\mathrm{NO}_{3}\end{array}$ & $\begin{array}{l}\text { Si could improve nitrate stress by enhancing } \\
\text { chlorophyll synthesis and } \mathrm{N} \text { - assimilation }\end{array}$ & $\begin{array}{l}\text { Gou et al. } \\
(2020 a)\end{array}$ \\
\hline $\begin{array}{l}\text { Dopamine } \\
\text { (up to } 200 \mu \mathrm{mol} \mathrm{L}{ }^{-1} \text { ) }\end{array}$ & $\begin{array}{l}\text { Nitrate stress } \\
\left.(500 \mu \mathrm{mol} \mathrm{L})^{-1}\right)\end{array}$ & $\begin{array}{l}\text { Dopamine mediated plant growth, } \mathrm{C} \text { and } \mathrm{N}- \\
\text { metabolism under nitrate stress }\end{array}$ & $\begin{array}{l}\text { Lan et al. } \\
(2020)\end{array}$ \\
\hline $\begin{array}{l}\text { Gamma-amino- } \\
\text { butyric acid (GABA) } \\
\text { up to } 40 \mathrm{mM} \text { for } 7 \mathrm{~d}\end{array}$ & $\begin{array}{l}\text { Nutrient stress } \\
\text { (Fe deficiency) }\end{array}$ & $\begin{array}{l}\text { GABA improved tolerance to Fe- deficiency } \\
\text { by reducing chlorosis; inhibition of growth } \\
\text { and photosynthesis }\end{array}$ & $\begin{array}{l}\text { Gou et al. } \\
(2020 b)\end{array}$ \\
\hline $\begin{array}{l}\mathrm{CO}_{2} \text { enrichment } \\
(400 \text { and } 800 \\
\left.\mu \mathrm{mol} \mathrm{mol}^{-1}\right)\end{array}$ & $\begin{array}{l}\text { Drought stress via } \\
\text { polyethylene glycol: } 5 \\
\text { and } 10 \%\end{array}$ & $\begin{array}{l}\mathrm{CO}_{2} \text { enrichment decreased abscisic acid } \\
\text { content; increased gibberellin and root } \\
\text { biomass }\end{array}$ & $\begin{array}{l}\text { Li et al. } \\
(2020 a)\end{array}$ \\
\hline $\begin{array}{l}\mathrm{CO}_{2} \text { enrichment } \\
\left(800 \mu \mathrm{mol} \mathrm{mol}^{-1}\right)\end{array}$ & $\begin{array}{l}\text { Salt stress }(80 \\
\left.\mathrm{mmol} \cdot \mathrm{L}^{-1} \mathrm{NaCl}\right)\end{array}$ & $\begin{array}{l}\text { Enriched- } \mathrm{CO}_{2} \text { alleviated salt stress by } \\
\text { regulating the invertase activity in leaves }\end{array}$ & $\begin{array}{l}\text { Li et al. } \\
\text { (2020b) }\end{array}$ \\
\hline $\begin{array}{l}\text { Samples were } \\
\text { collected from } 1 \text { to } 12 \\
\mathrm{~h} \text { after treating }\end{array}$ & $\begin{array}{l}\text { Salt stress } \\
(75 \mathrm{mM} \mathrm{NaCl})\end{array}$ & $\begin{array}{l}\text { CsPNG1 genes may respond to improving } \\
\text { plant tolerance to abiotic stresses and hormone } \\
\text { treatments }\end{array}$ & $\begin{array}{l}\text { Hou et al. } \\
(2020)\end{array}$ \\
\hline $\begin{array}{l}\text { Foliar applied } \\
\text { spermidine }(1 \mathrm{mM})\end{array}$ & $\begin{array}{l}\text { Salt stress } \\
(100 \mathrm{mM} \mathrm{NaCl})\end{array}$ & $\begin{array}{l}\text { Exogenous spermidine increased cucumber } \\
\text { tolerant to salt stress by inducing } \\
\text { accumulation of gibberellin }\end{array}$ & $\begin{array}{l}\text { Wang et al. } \\
(2020)\end{array}$ \\
\hline $\begin{array}{l}\text { Applied } \mathrm{Ca}^{2+}(50 \\
\left.\mu \mathrm{molL} \mathrm{L}^{-1}\right) \text { and NO } \\
\left(200 \mu \mathrm{molL}^{-1}\right)\end{array}$ & $\begin{array}{l}\text { Low temperature } \\
\text { stress: } 11 / 7^{\circ} \mathrm{C}\end{array}$ & $\begin{array}{l}\mathrm{Ca}^{2+} \text { shared in the NO-induced low } \\
\text { temperature tolerant by modulating processes } \\
\text { of PSII, carbohydrate metabolism and leaf } \\
\text { gas exchange }\end{array}$ & $\begin{array}{l}\text { Zhang et al. } \\
(2020 b)\end{array}$ \\
\hline $\begin{array}{l}\text { 2-hydroxy-melatonin } \\
\text { (up to } 150 \mu \mathrm{M} \text { ) }\end{array}$ & $\begin{array}{l}\text { Cadmium stress } \\
\left(50 \mathrm{mg} \mathrm{kg}^{-1} \mathrm{Cd}\right)\end{array}$ & $\begin{array}{l}\text { Improved antioxidant activity, reduction } \\
\text { of } \mathrm{H}_{2} \mathrm{O}_{2} \text {, electrolyte leakage and } \\
\text { malondialdehyde under Cd-stress }\end{array}$ & $\begin{array}{l}\text { Shah et al. } \\
(2020)\end{array}$ \\
\hline $\begin{array}{l}\text { Foliar up to } 2.5 \mathrm{mM} \\
\mathrm{NaHS} \text { and } 100 \mu \mathrm{M} \\
\text { IAA }\end{array}$ & Chilling stress $\left(5^{\circ} \mathrm{C}\right)$ & $\begin{array}{l}\mathrm{H}_{2} \mathrm{~S} \& \text { IAA alleviate harm chilling stress by } \\
\text { preventing excessive ROS accumulation and } \\
\text { activating enzymatic antioxidants }\end{array}$ & $\begin{array}{l}\text { Zhang et al. } \\
\text { (2020a) }\end{array}$ \\
\hline $\begin{array}{l}\text { Foliar } 2.5 \mathrm{mM} \mathrm{NaHS} \\
\text { and up to } 15 \mathrm{mM} \\
\mathrm{H}_{2} \mathrm{O}_{2}\end{array}$ & Chilling stress $\left(5^{\circ} \mathrm{C}\right)$ & $\begin{array}{l}\mathrm{H}_{2} \mathrm{~S} \text { alleviates chilling stress by improving } \\
\text { C-metabolism and its assimilation, photo- } \\
\text { protection for PSII and PSI }\end{array}$ & $\begin{array}{l}\text { Liu et al. } \\
(2020 b)\end{array}$ \\
\hline $\begin{array}{l}\text { Foliar } 1.0 \mathrm{mM} \text { NaHS } \\
\text { at } 2^{\text {nd }} \text { leaf stage for } \\
6 \mathrm{~h}\end{array}$ & Chilling stress $\left(5^{\circ} \mathrm{C}\right)$ & $\begin{array}{l}\text { Glutathione has downstream signal of } \mathrm{H}_{2} \mathrm{~S} \text { - } \\
\text { induced plant tolerance to chilling stress }\end{array}$ & $\begin{array}{l}\text { Liu et al. } \\
(2020 a)\end{array}$ \\
\hline
\end{tabular}

Due to the huge differences among abiotic stresses and their mode of actions on greenhouse cucumber production, some studies have shown the beneficial effects of many anti-stresses, but others showed a deficit in particular the combined or multiple stresses. This indicates a need to understand the various perceptions of combined and multiple stresses that exist among these stresses particularly in arid zones. Drought, salinity and alkalinity stresses are common in arid climate environments (Alsaeedi et al., 2019; Baiet al., 2019; Trabelsi et al., 2019 and Jamshidi Goharrizi et al., 2020). In arid environments, continues upward waterfrom soil surfaces and plants due to evapotranspiration may lead to concentrate and increase salt levels near soil surfaces (Amer et al., 2019). Thus, drought stress routinely may overlap with soil salinity, and these both affect plant growth and productivity together (Bai et al., 2019). The simultaneous 
stress resulting from aluminum toxicity, drought and salinity on the growth of lettuce seedlings also has investigated under acidic Andisols in Chile (Silambarasan et al., 2019). Distinguished shift in molecular responses could be exhibited by combined stresses on plants compared with the same stresses independently as investigated on the combined stress of drought and bacterial pathogen (Gupta et al., 2020). More studies have been reported about the combined and individual stresses such as combined drought-flooding conditions in saline-alkaline lands (Wen et al., 2017), drought and heat stress on tomato plants (Duc et al., 2018), salinity and drought on cabbage (Sahin et al., 2018), drought and heat stress on banana (Chaudhari et al., 2019), drought on sugar beet grown in Cd-contaminated saline soil (Abd El-Mageed et al., 2019), and salinity and drought on spinach (Ibekwe et al., 2020). Therefore, there are severalsubstances, compounds and nutrients could be applied to ameliorate different abiotic stresses on cucumber, which depends on the type of stress such as exogenous application of salicylic acid, melatonin, chitosan, putrescine, spermidine, selenium, silicon, nanomaterials, $\mathrm{H}_{2} \mathrm{~S}, \mathrm{H}_{2} \mathrm{O}_{2}$, etc.

\section{Management of Abiotic Stress in Greenhouse Cucumber}

Under environmental stresses, cultivated plants have the ability to generatemany reactive compounds such as reactive oxygen species, reactive nitrogen species, and reactive carbonyl compounds (Czarnocka and Karpiński, 2018; Kapoor et al., 2019 and Nareshkumar et al., 2020). These species might play a harmful role in different plant processesunder stressleading to oxidative stress, whichimpacts the plant growth severely under these abiotic factors (Nareshkumar et al., 2020). Each abiotic stress has distinguished features on greenhouse cucumber and special mitigation or management. For more explanation, each individual abiotic stress will be handled in this review including the general features of the stress on cucumber and different approaches, which could be applied against this stress. Concerning the most important abiotic stresses, drought and salinity are very common worldwide and they are together considered a serious threat casing a very high loss in cucumber crop production. Globally, desertification and salinization are resulted from drought and salinity, which are in rapid increasing phenomena (Ouzounidou et al., 2016). The salinity of water and/or soil could be considered a main contribution in abiotic stress, which may constrain the greenhouse productionparticularly in arid and semi-arid and regions (Minhas et al., 2020). The salinity stress may depress cucumber growth and its development due to inducing water deficit. This water deficit will causeionspecific toxicity (mainly $\mathrm{Na}^{+}, \mathrm{Cl}^{-}$and $\mathrm{NO}_{3}^{-}$) and a secondary oxidative stress (Sang et al. 2016). Under salinity stress, the water deficit in leaves will enforce plants to close the stomata, reduce the photosynthetic rates and thenaccelerate the oxidativestress (Hasanuzzaman et al., 2019; Mohsin et al., 2019). This oxidative stress will generate a lot of reactive oxygen species (Khodayari et al., 2018) and cause a trouble in plant antioxidant system (Kapoor et al., 2019).

It could be mitigated the oxidative stress, which results from stress and develop plant tolerance against these stresses through exogenous application of biostimulants such as plant growth hormones like gibberellin (Wang et al., 2020), trace elements like selenium (Jóźwiak and Politycka, 2019), signaling molecules (Khan et al., 2019) and organic chemicalsas well as some fungicides such astriazole and strobilurin (Mohsin et al., 2019). Many studies have handled the mitigation and amelioration of the oxidative damage in cucumber under salinity stress through the exogenous application of several nutrients or anti-stresses such as silicon by increasing the accumulation of polyaminesand decreasing oxidative damage (Yin et al., 2019; Zhu et al., 2019 and Gou et al., 2020a), nitric oxide by enhancing antioxidant enzymes (Fan et al., 2013), silica nanoparticles by balancing nutrients uptake (Alsaeedi et al., 2019), kinetin by stimulating the salt tolerance (Gurmani et al., 2018), salicylic acidby controlling endogenous salicylic acid levels or peroxidase (Kim et al., 2017 and Youssef et al., 2018), aminolevulinic acid by enhancing ascorbate-glutathione cycle (Wu et al., 2019b), some industrial solid wastes like sugar factory wastes by decreasing the health risk of heavy metals (Taghipour and Jalali, 2019), melatonin or its derived by improving the photosynthetic capacity (Wang et al., 2016; Santosh and Prianka, 2020; Shah et al., 2020 and Zhang et al., 2020c). It could be also exogenous applied polyamines including putrescine (Shen et al., 2019; Shuet al., 2019 and Yuan et al., 2019), spermine (Yin et al., 2019) and spermidine (Wu et al., 2018 and Wang et al., 2020) as anti-stresses. The elevated $\mathrm{CO}_{2}$ (up to $800 \mu \mathrm{mol} \mathrm{mol}^{-1}$ ) also can promote $\mathrm{K}^{+}$ accumulation in cucumber plants under salt stress with reducing the $\mathrm{Na}^{+} / \mathrm{K}^{+}$ratio, maintaining the 
ion balance and ensuring the enzymatic activities (Li et al., 2019a, 2020b). The applied grafting on cucumber under irrigation with saline water has alleviated crop salt stress (Wang et al. 2017 and Usanmaz and Abak, 2019).

Under changing climate, drought stress has become more frequent and severe, threatening the future of crop productivity and the security of global foods (Mphande et al., 2020). The general features of drought stress on stressed cucumber plants mainly include serious problem in plant water content and its high loss rate, which impair many metabolic and physiological processes as well as the activity of antioxidants and high osmotic stress (Fan et al., 2014 and Mphande et al., 2020). For the avoidance of cucumber drought and water deficit stress, the plants should be adaptive effective strategies in this context. These effective strategies may include the applied biostimulants such as silicon to mitigate lipid peroxidation (Ouzounidou et al., 2016), nano silica by creating abalance in the uptake of nutrients (Alsaeedi et al., 2019), elevated $\mathrm{CO}_{2}$ through the regulation of phytohormone contents in cucumber roots ( $\mathrm{Li}$ et al., 2018; Cui et al., 2019 and Li et al., 2020a), applied hydrogen peroxide by increasing the plant antioxidative defense system (Li et al., 2016; Sun et al., 2016 and Li et al., 2018), applied zeolite and hydrogel by enhanced water retention capacity (Gholamhoseini et al., 2018).

\section{Conclusion}

Cucumber is considered one of the most important vegetable crops worldwide ranking its global production a distinguished position among the highest five vegetable crops. This production could be performed under greenhouse or open field systems. The greenhouse cucumber production totally differs in developed and developing countries due to the available facilities. The greenhouses of low cost structures are very common in developing countries, which the cucumber production suffers from several problems or stresses. The abiotic stresses including salinity, drought, heavy metals and heat stress are common in arid environments representing a main reason in crop yield loss. There are many strategies or approaches are required to overcome these stresses such as chemical compounds (e.g., salicylic acid, melatonin, chitosan, putrescine, spermidine, $\mathrm{H}_{2} \mathrm{~S}$, and $\mathrm{H}_{2} \mathrm{O}_{2}$ ), foliar application of some nutrients (e.g., selenium, silicon) and some nanomaterials or nanoparticles as well as grafting. These previous materials or nutrients have the ability to support cultivated cucumber against the abiotic stress and overcome the oxidative stress. Due to the unique of arid environments, the multiple stresses are common in these regions particularly salinity, drought and heat stresses. The general features of salinity stress are represented in causing mainly ionic toxicity, which deteriorate the physiological, morphological and biochemical processes incucumber plants. Salinity and drought stress also can reduce the photosynthesisrate and increase ROS, whichare very toxic causing cell damage including lipid peroxidation, protein denaturing and then death of plant cells. The individual stress on cucumber plants was handled in details in many studies, but the combined stresses are still in urgent need for further investigations based on the physiological, biochemical, anatomical and molecular levels.

\section{Acknowledgement}

The Authors thank the staff members of Physiology and Breeding of Horticultural Crops Laboratory, Dept. of Horticulture, Fac. of Agric., Kafrelsheikh University, Kafr El-Sheikh, Egypt for supporting this work.

\section{References}

Abdalla, N., Taha, N., El-Ramady, H., Bayoumi, Y. (2020) Management of Heat Stress in Tomato Seedlings under Arid and Semi-Arid Regions: A Review. Env. Biodiv. Soil Security, 4, DOI: 10.21608/JENVBS.2020.28143.1089

Abd El-Mageed, T. A., El-Sherif, A. M. A., Abd ElMageed, S. A., Abdou, N. M. (2019) A novel compost alleviate drought stress for sugar beet production grown in Cd-contaminated saline soil. Agricultural Water Management, 226, 105831. doi:10.1016/j.agwat.2019.105831

Ali, A., Ghani, M., Ding, H., Fan, Y., Cheng, Z., Iqbal, M. (2019b) Co-Amended Synergistic Interactions between Arbuscular Mycorrhizal Fungi and the Organic Substrate-Induced Cucumber Yield and Fruit Quality Associated with the Regulation of the AM-Fungal Community Structure under Anthropogenic Cultivated Soil. Int J Mol Sci. 20(7), 1539. doi:10.3390/ijms20071539

Ali, A., Imran Ghani, M., Li, Y., Ding, H., Meng, H., Cheng, Z. (2019a) Hiseq Base Molecular Characterization of Soil Microbial Community, Diversity Structure, and Predictive Functional Profiling in Continuous Cucumber Planted Soil Affected by Diverse Cropping Systems in an 
Intensive Greenhouse Region of Northern China. Int J Mol Sci. 20(11), 2619. doi:10.3390/ijms20112619

Alsaeedi, A.. El-Ramady, H., Alshaal, T., El-Garawany, M., Elhawat, N., Al-Otaib, A. (2019) Silica nanoparticles boost growth and productivity of cucumber under water deficit and salinity stresses by balancing nutrients uptake. Plant Physiology and Biochemistry, 139: 1-10. https://doi.org/10.1016/j. plaphy.2019.03.008

Amer, M., Aiad, M., Rashed, S., El-Ramady, H. (2019) Sustainable Irrigation and Fertilization Management of Successive Cultivated Sugar Beet and Cotton under Salt-affected Soil Conditions. Env. Biodiv. Soil Security,3: 227 - 239. DOI: 10.21608/jenvbs.2019.20394.1076

Asgharipour, M. R., Amiri, Z., Campbell, D. E. (2020) Evaluation of the sustainability of four greenhouse vegetable production ecosystems based on an analysis of emergy and social characteristics. Ecological Modelling, 424, 109021. doi:10.1016/j. ecolmodel.2020.109021

Bai, X., Dai, L., Sun, H., Chen, M., Sun, Y. (2019) Effects of moderate soil salinity on osmotic adjustment and energy strategy in soybean under drought stress. Plant Physiology and Biochemistry,139, 307-313. https://doi.org/10.1016/j.plaphy.2019.03.029

Chaudhari, R. S., Jangale, B. L., Azeez, A., Krishna, B., Sane, P. V., Sane, A. P. (2019) Differential regulation of the banana stress NAC family by individual and combined stresses of drought and heat in susceptible and resistant genotypes. Plant Physiology and Biochemistry, 145, 184-194. https://doi.org/10.1016/j.plaphy.2019.10.040

Cong, Y., Fan, H., Ma, Q., Lu, Y., Xu, L., Zhang, P., Chen, K. (2019) Mixed culture fermentation between Rhizopus nigricans and Trichoderma pseudokoningii to control cucumber Fusarium wilt. Crop Protection, 104857. doi:10.1016/j. cropro.2019.104857

Cui, B.-J., Niu, W.-Q., Du, Y.-D., Zhang, Q. (2020) Response of yield and nitrogen use efficiency to aerated irrigation and $\mathrm{N}$ application rate in greenhouse cucumber. Scientia Horticulturae, 265, 109220. doi:10.1016/j.scienta.2020.109220

Cui, Q., Li, Y., He, X., Li, S., Zhong, X., Liu, B., Zhang, D., Li, Q. (2019) Physiological and iTRAQ based proteomics analyses reveal the mechanism of elevated $\mathrm{CO}_{2}$ concentration alleviating drought stress in cucumber (Cucumis sativus L.) seedlings. Plant Physiology and Biochemistry, 143, 142-153. doi:10.1016/j.plaphy.2019.08.025

Czarnocka, W., Karpiński, S. (2018) Friend or foe? Reactive oxygen species production, scavenging and signaling in plant response to environmental stresses. Free Radical Biology and Medicine, 122, 4-20. doi:10.1016/j.freeradbiomed.2018.01.011

Derbalah, A. S., Elsharkawy, M. M. (2019) A new strategy to control Cucumber mosaic virus using fabricated NiO-nanostructures. J. Biotechnology, 306, 134-141. doi:10.1016/j.jbiotec.2019.10.003

Dong, J., Gruda, N., Li, X., Tang, Y., Duan, Z. (2020b) Impacts of elevated $\mathrm{CO}_{2}$ on nitrogen uptake of cucumber plants and nitrogen cycling in a greenhouse soil. Applied Soil Ecology, 145. doi:10.1016/j.apsoil.2019.08.004

Dong, J., Gruda, N., Li, X., Tang, Y., Zhang, P., Duan, Z. (2020a) Sustainable vegetable production under changing climate: The impact of elevated $\mathrm{CO}_{2}$ on yield of vegetables and the interactions with environments-A review. J. Cleaner Production, 253, 119920. doi:10.1016/j.jclepro.2019.119920

Duc, N. H., Csintalan, Z., Posta, K. (2018) Arbuscular mycorrhizal fungi mitigate negative effects of combined drought and heat stress on tomato plants. Plant Physiology and Biochemistry,132, 297-307. doi:10.1016/j.plaphy.2018.09.011

El-Ramady, H., Olle, M., Eichler-Löbermann, B., Schnug, E. (2020) Towards a New Concept of Sustainable Plant Nutrition.Env. Biodiv. Soil Security,4: 1-5. DOI: 10.21608/ JENVBS.2020.21970.1080

El-Ramady, H., Abowaly, M., Elbehiry, F., Omara,A. E., Elsakhawy, T., Mohamed, A Belal,E.S., Elbasiouny,H., Fawzy, Z.F. (2019) Stressful Environments and Sustainable Soil Management: A Case Study of Kafr El-Sheikh, Egypt. Env. Biodiv. Soil Security,3: 193 - 213. DOI: 10.21608/ jenvbs.2019.17750.1070

Eskandari, S., Höfte, H., Zhang, T. (2020) Foliar Manganese spray induces the resistance of cucumber to Colletotrichum lagenarium. J. Plant Physiology, 153129. doi:10.1016/j.jplph.2020.153129

Eskandari, S., Sharifnabi, B. (2019) The modifications of cell wall composition and water status of cucumber leaves induced by powdery mildew and manganese nutrition. Plant Physiology and Biochemistry, 145, 132-141. doi:10.1016/j.plaphy.2019.10.037

Fan, H.-F., Ding, L., Du, C.-X., Wu, X. (2014) Effect of short-term water deficit stress on antioxidative 
systems in cucumber seedling roots. Botanical Studies, 55(1), 46. doi:10.1186/s40529-014-0046-6

Fan, H.-F., Du, C.-X., Ding, L., Xu, Y.-L. (2013) Effects of nitric oxide on the germination of cucumber seeds and antioxidant enzymes under salinity stress. Acta Physiologiae Plantarum, 35(9), 2707-2719. doi:10.1007/s11738-013-1303-0

Fan, Y., Zhang, Y., Hess, F., Huang, B., Chen, Z. (2020) Nutrient balance and soil changes in plastic greenhouse vegetable production. Nutrient Cycling in Agroecosystems, 117: 77-92. doi:10.1007/ s10705-020-10057-x

Gholamhoseini, M., Habibzadeh, F., Ataei, R., Hemmati, P., Ebrahimian, E. (2018). Zeolite and hydrogel improve yield of greenhouse cucumber in soil-less medium under water limitation. Rhizosphere, 6, 7-10. doi:10.1016/j.rhisph.2018.01.006

Gou, T., Yang, L., Hu, W., Chen, X., Zhu, Y., Guo, J., Gong, H. (2020a) Silicon improves the growth of cucumber under excess nitrate stress by enhancing nitrogen assimilation and chlorophyll synthesis. Plant Physiology and Biochemistry. doi:10.1016/j. plaphy.2020.04.031

Gou, Z., Du, N., Li, Y., Zheng, S., Shen, S., Piao, F. (2020b) Gamma-aminobutyric acid enhances tolerance to iron deficiency by stimulating auxin signaling in cucumber (Cucumis sativus L.). Ecotoxicology and Environmental Safety, 192, 110285. doi:10.1016/j.ecoenv.2020.110285

Gupta, A., Patil, M., Qamar, A., Senthil-Kumar, M. (2020) ath-miR164c influences plant responses to the combined stress of drought and bacterial infection by regulating proline metabolism, Environmental and Experimental Botany, 172, doi: https://doi.org/10.1016/j.envexpbot.2020.103998

Gurmani, A. R., Khan, S. U., Ali, A., Rubab, T., Schwinghamer, T., Jilani, G., Farid, A., Zhang, J. (2018) Salicylic acid and kinetin mediated stimulation of salt tolerance in cucumber (Cucumis sativus L.) genotypes varying in salinity tolerance. Horticulture, Environment, and Biotechnology, 59(4), 461-471. doi:10.1007/s13580-018-0056-5

Hafez, Y. M., Attia, K. A., Kamel, S., Alamery, S. F., El-Gendy, S., Al-Doss, A. A., Mehiar, F., Ghazy A.I., Mohammed, A., Abdelaal, K. A. A. (2020) Bacillus subtilis as a bio-agent combined with nano molecules can control powdery mildew disease through histochemical and physiobiochemical changes in cucumber plants. Physiological and Molecular Plant Pathology, 101489. doi:10.1016/j. pmpp.2020.101489

Hasanuzzaman, M., Borhannuddin Bhuyan, M. H. M., Anee, T. I., Parvin, K., Nahar, K., Al Mahmud, J., Fujita, M. (2019) Regulation of AscorbateGlutathione Pathway in Mitigating Oxidative Damage in Plants under Abiotic Stress. Antioxidants (Basel)8(9): 384. doi: 10.3390/antiox 8090384

Hou, K., Wang, Y., Tao, M.-Q., Jahan, M. S., Shu, S., Sun, J., Guo, S.-R. (2020) Characterization of the CsPNG1 gene from cucumber and its function in response to salinity stress. Plant Physiology and Biochemistry, 150, 140-150. doi:10.1016/j. plaphy.2020.02.027

Ibekwe, A. M., Ors, S., Ferreira, J. F. S., Liu, X., Suarez, D. L., Ma, J., Ghasemimianaei, A., Yang, C.-H. (2020) Functional relationships between aboveground and belowground spinach (Spinacia oleracea L., cv. Racoon) microbiomes impacted by salinity and drought. Science of The Total Environment, 137207. doi:10.1016/j. scitotenv.2020.137207

Iddio, E., Wang, L., Thomas, Y., McMorrow, G., Denzer, A. (2020) Energy efficient operation and modeling for greenhouses: A literature review. Renewable and Sustainable Energy Reviews, 117, https://doi.org/10.1016/j.rser.2019.109480

Jamshidi Goharrizi, K., Baghizadeh, A., Kalantar, M., Fatehi, F. (2020) Combined effects of salinity and drought on physiological and biochemical characteristics of pistachio rootstocks. Scientia Horticulturae, 261, 108970. doi:10.1016/j. scienta.2019.108970

Jóźwiak, W., Politycka, B. (2019) Effect of Selenium on Alleviating Oxidative Stress Caused by a Water Deficit in Cucumber Roots. Plants (Basel)8(7): 217. doi: $10.3390 /$ plants 8070217

Kapoor, D., Singh, S., Kumar, V., Romero, R., Prasad, R., Singh, J. (2019) Antioxidant enzymes regulation in plants in reference to reactive oxygen species (ROS) and reactive nitrogen species (RNS). Plant Gene, 19, 100182. doi:10.1016/j. plgene.2019.100182

Kashyap, P. L., Rai, P., Srivastava, A. K., Kumar, S. (2017)Trichoderma for climate resilient agriculture. World J. Microbiol Biotechnol, 33:155 DOI 10.1007/s11274-017-2319-1

Khan, M. I. R., Reddy, P. S., Ferrante, A., Khan, N. (2019) Plant Signaling Molecule: Role and Regulation under Stressful Environments. 
Woodhead Publishing,

Khodayari, S., Abedini, F., Renault, D. (2018) The responses of cucumber plants subjected to different salinity or fertilizer concentrations and reproductive success of Tetranychus urticae mites on these plants. Exp Appl Acarol75:41-53. https:// doi.org/10.1007/s10493-018-0246-y

Kim, Y., Kim, S., Shim, I.-S. (2017). Exogenous salicylic acidalleviates salt-stress damage in cucumber under moderate nitrogen conditions by controlling endogenous salicylic acid levels. Horticulture, Environment, and Biotechnology, 58(3), 247-253. doi:10.1007/s13580-017-0111-7

Lan, G., Jiao, C., Wang, G., Sun, Y., Sun, Y. (2020) Effects of dopamine on growth, carbon metabolism, and nitrogen metabolism in cucumber under nitrate stress. Scientia Horticulturae, 260, 108790. doi:10.1016/j.scienta.2019.108790

Li, M., Li, Y., Zhang, W., Li, S., Gao, Y., Ai, X., Zhang, D., Liu, B., Li, Q. (2018) Metabolomics analysis reveals that elevated atmospheric $\mathrm{CO}_{2}$ alleviates drought stress in cucumber seedling leaves. Analytical Biochemistry, 559, 71-85. doi:10.1016/j. ab.2018.08.020

Li, M., Ma, G., Lian, H., Su, X., Tian, Y., Huang, W., Mei, J., Jiang, X. (2019b) The effects of Trichoderma on preventing cucumber fusarium wilt and regulating cucumber physiology. J. Integrative Agriculture, 18(3), 607-617. doi:10.1016/s20953119(18)62057-x

Li, S., Li, Y., Gao, Y., He, X., Zhang, D., Liu, B., Li, Q. (2020b) Effects of $\mathrm{CO}_{2}$ enrichment on non-structural carbohydrate metabolism in leaves of cucumber seedlings under salt stress. Scientia Horticulturae, 265, 109275. doi:10.1016/j.scienta.2020.109275

Li, S., Li, Y., He, X., Li, Q., Liu, B., Ai, X., Zhang, D. (2019a) Response of water balance and nitrogen assimilation in cucumber seedlings to $\mathrm{CO}_{2}$ enrichment and salt stress. Plant Physiology and Biochemistry, 139, 256-263 doi:10.1016/j. plaphy.2019.03.028

Li, X.-P., Xu, Q.-Q., Liao, W.-B., Ma, Z.-J., Xu, X.-T., Wang, M., Ren, P.-J., Niu, J.-L., Jin, X., Zhu, Y.-C. (2016) Hydrogen peroxide is involved in abscisic acid-induced adventitious rooting in cucumber (Cucumis sativus L.) under drought stress. J. Plant Biology, 59(5), 536-548. doi:10.1007/s12374-0160036-1

Li, Y., Li, S., He, X., Jiang, W., Li, Q. (2020a) $\mathrm{CO}_{2}$ enrichment enhanced drought resistance by regulating growth, hydraulic conductivity and phytohormone contents in the root of cucumber seedlings. Plant Physiology and Biochemistry, https://doi.org/10.1016/j.plaphy.2020.04.037

Liang, H., Hu, K., Batchelor, W. D., Qin, W., Li, B. (2018) Developing a water and nitrogen management model for greenhouse vegetable production in China: Sensitivity analysis and evaluation. Ecological Modelling, 367, 24-33. doi:10.1016/j.ecolmodel.2017.10.016

Liu, B. B., Li, M., Li, Q. M., Cui, Q. Q., Zhang, W. D., Ai, X. Z., Bi, H. G. (2018) Combined effects of elevated $\mathrm{CO}_{2}$ concentration and drought stress on photosynthetic performance and leaf structure of cucumber (Cucumis sativus L.) seedlings. Photosynthetica, 56(3), 942-952. doi:10.1007/ s11099-017-0753-9

Liu, F., Fu, X., Wu, G., Feng, Y., Li, F., Bi, H., Ai, X. (2020b) Hydrogen peroxide is involved in hydrogen sulfide-induced carbon assimilation and photoprotection in cucumber seedlings. Environmental and Experimental Botany, 175, 104052. doi:10.1016/j.envexpbot.2020.104052

Liu, F., Zhang, X., Cai, B., Pan, D., Fu, X., Bi, H., Ai, X. (2020a) Physiological Response and Transcription Profiling Analysis Reveal the Role of Glutathione in H2S-induced Chilling Stress Tolerance of Cucumber Seedlings. Plant Science, 291, 110363. doi:10.1016/j.plantsci.2019.110363

Liu, X., Li, Y., Ren, X., Chen, B., Zhang, Y., Shen, C., Wang, F., Wu, D. (2020c) Long-Term Greenhouse Cucumber Production Alters Soil Bacterial Community Structure. J. Soil Science and Plant Nutrition,20, 306-321. https://doi.org/10.1007/ s42729-019-00109-9 (2020) 20:306-321

Minhas, P. S., Ramos, T. B., Ben-Gal, A., Pereira, L. S. (2020) Coping with salinity in irrigated agriculture: Crop evapotranspiration and water management issues. Agric Water Manag, 227, 105832. doi:10.1016/j.agwat.2019.105832

Mohsin, S. M., Hasanuzzaman, M., Bhuyan, M. H. M. B., Parvin, K., Fujita, M. (2019) Exogenous Tebuconazole and Trifloxystrobin Regulates Reactive Oxygen Species Metabolism Toward Mitigating Salt-Induced Damages in Cucumber Seedling. Plants8 (10), 428. doi:10.3390/ plants 8100428

Mphande, W., Kettlewell, P. S., Grove, I. G., Farrell, A. D. (2020) The potential of antitranspirants in 
drought management of arable crops: A review. Agricultural Water Management, 236, 106143. doi:10.1016/j.agwat.2020.106143

Nareshkumar, A., Subbarao, S., Vennapusa, A. R., Ashwin, V., Banarjee, R., Kulkarni, M. J., Ramu, V. S., Udayakumar, M. (2020) Enzymatic and Non-enzymatic Detoxifcation of Reactive Carbonyl Compounds Improves the Oxidative Stress Tolerance in Cucumber, Tobacco and Rice Seedlings. J. Plant Growth Regul.https://doi. org/10.1007/s00344-020-10072-w

Ouzounidou, G., Giannakoula, A., Ilias, I., Zamanidis, P. (2016) Alleviation of drought and salinity stresses on growth, physiology, biochemistry and quality of two Cucumis sativus L. cultivars by $\mathrm{Si}$ application. Brazilian J. Botany, 39(2), 531-539. doi:10.1007/ s40415-016-0274-y

Phogat, V., Mallants, D., Cox, J. W., Šimůnek, J., Oliver, D. P., Awad, J. (2020) Management of soil salinity associated with irrigation of protected crops. Agricultural Water Management,227, 105845. doi:10.1016/j.agwat.2019.105845

Punja, Z. K., Tirajoh, A., Collyer, D., Ni, L. (2019) Efficacy of Bacillus subtilis strain QST 713 (Rhapsody) against four major diseases of greenhouse cucumbers. Crop Protection, 124, 104845. doi:10.1016/j.cropro.2019.104845

Qi, Q., Guo, Z., Liang, Y., Li, K., Xu, H. (2019) Hydrogen sulfide alleviates oxidative damage under excess nitrate stress through MAPK/NO signaling in cucumber. Plant Physiology and Biochemistry, 135, 1-8. doi:10.1016/j.plaphy.2018.11.017

Sahin, U., Ekinci, M., Ors, S., Turan, M., Yildiz, S., Yildirim, E. (2018) Effects of individual and combined effects of salinity and drought on physiological, nutritional and biochemical properties of cabbage (Brassica oleracea var. capitata). Scientia Horticulturae, 240, 196-204. doi:10.1016/j.scienta.2018.06.016

Sang, T., Shan, X., Li, B., Shu, S., Sun, J., Guo, S. (2016) Comparative proteomic analysis reveals the positive effect of exogenous spermidine on photosynthesis and salinity tolerance in cucumber seedlings. Plant Cell Reports, 35(8), 1769-1782. doi:10.1007/s00299-016-1995-x

Santosh, K. B., Prianka, H. (2020) Melatonin Plays Multifunctional Role in Horticultural Crops Against Environmental Stresses: A Review. Environmental and Experimental Botany, 176, 104063. doi:10.1016/j.envexpbot.2020.104063
Shah, A. A., Ahmed, S., Ali, A., Yasin, N. A. (2020) 2-Hydroxymelatonin mitigates cadmium stress in cucumis sativus seedlings: Modulation of antioxidant enzymes and polyamines. Chemosphere, 243, 125308. doi:10.1016/j. chemosphere.2019.125308

Sharma, S., Kour, D., Rana, K. L., Dhiman, A., Thakur, S., Thakur, P., Thakur, S., Thakur, N., Sudheer, S., Yadav, N., Yadav, A. N., Rastegari, A. A., Singh, K. (2019)Trichoderma: Biodiversity, Ecological Significances, and Industrial Applications. In: A. N. Yadav et al. (eds.), Recent Advancement in White Biotechnology Through Fungi, Fungal Biology, https://doi.org/10.1007/978-3-030-10480-1_3, Springer Nature Switzerland AG, pp: $85-120$.

Shen, J., Wang, Y., Shu, S., Jahan, M. S., Zhong, M., Wu, J., Sun, J., Guo, S. (2019) Exogenous putrescine regulates leaf starch overaccumulation in cucumber under salt stress. Scientia Horticulturae, 253, 99 110. doi:10.1016/j.scienta.2019.04.010

Shen, M., Huang, W., Chen, M., Song, B., Zeng, G., Zhang, Y. (2020) (Micro)plastic crisis: Un-ignorable contribution to global greenhouse gas emissions and climate change. J. Cleaner Production, 120138. doi:10.1016/j.jclepro.2020.120138

Shu, S., Yuan, R., Shen, J., Chen, J., Wang, L., Wu, J., Sun, J., Wang, Y., Shirong, G. (2019) The Positive Regulation of Putrescine on Light-Harvesting Complex II and Excitation Energy Dissipation in Salt-Stressed Cucumber Seedlings. Environmental and Experimental Botany, 162, 283-294. doi:10.1016/j.envexpbot.2019.02.027

Silambarasan, S., Logeswari, P., Cornejo, P., Abraham, J., Valentine, A. (2019) Simultaneous mitigation of aluminum, salinity and drought stress in Lactuca sativa growth via formulated plant growth promoting Rhodotorula mucilaginosa CAM4. Ecotoxicology and Environmental Safety, 180, 63 72. doi:10.1016/j.ecoenv.2019.05.006

Song, C., Ye, F., Zhang, H., Hong, J., Hua, C., Wang, B., Chen, Y., Ji, R., Zhao, L. (2019) Metal(loid) Oxides and Metal Sulfides Nanomaterials Reduced Heavy Metals Uptake in Soil Cultivated Cucumber Plants. Environmental Pollution, 255, Part 3, 113354. doi:10.1016/j.envpol.2019.113354

Sun, Y., Wang, H., Liu, S., Peng, X. (2016) Exogenous application of hydrogen peroxide alleviates drought stress in cucumber seedlings. South African J. Botany, 106, 23-28. doi:10.1016/j. sajb.2016.05.008 
Sun, Y., Zhang, J., Wang, H., Wang, L., Li, H. (2019) Identifying optimal water and nitrogen inputs for high efficiency and low environment impacts of a greenhouse summer cucumber with a model method. Agricultural Water Management,212, 2334. doi:10.1016/j.agwat.2018.08.028

Szczech, M., Nawrocka, J., Felczyński, K., Małolepsza, U., Sobolewski, J., Kowalska, B., Maciorowski, R., Jas, K., Kancelista, A. (2017) Trichoderma atroviride TRS25 isolate reduces downy mildew and induces systemic defence responses in cucumber in field conditions. Scientia Horticulturae, 224, 1726. doi:10.1016/j.scienta.2017.05.035

Taghipour, M., Jalali, M. (2019) Impact of some industrial solid wastes on the growth and heavy metal uptake of cucumber (Cucumis sativus L.) under salinity stress. Ecotoxicology and Environmental Safety, 182, 109347. doi:10.1016/j. ecoenv.2019.06.030

Taki, M., Yildizhan, H. (2018) Evaluation the sustainable energy applications for fruit and vegetable productions processes; case study: Greenhouse cucumber production. J. Cleaner Production, 199, 164-172. doi:10.1016/j.jclepro.2018.07.136

Trabelsi, L., Gargouri, K., Ben Hassena, A., Mbadra, C., Ghrab, M., Ncube, B., Staden, J. V., Gargouri, R. (2019) Impact of drought and salinity on olive water status and physiological performance in an arid climate. Agricultural Water Management, 213, 749-759. doi:10.1016/j.agwat.2018.11.025

Usanmaz, S., Abak, K. (2019) Plant growth and yield of cucumber plants grafted on different commercial and local rootstocks grown under salinity stress. Saudi J. Biological Sciences. doi:10.1016/j. sjbs.2018.07.010

Wang, A., Gallardo, M., Zhao, W., Zhang, Z., Miao, M. (2019) Yield, nitrogen uptake and nitrogen leaching of tunnel greenhouse grown cucumber in a shallow groundwater region. Agricultural Water Management, 217, 73-80. doi:10.1016/j. agwat.2019.02.026

Wang, L. Y., Liu, J. L., Wang, W. X., Sun, Y. (2016) Exogenous melatonin improves growth and photosynthetic capacity of cucumber under salinity-induced stress. Photosynthetica, 54 (1), 19-27. doi:10.1007/s11099-015-0140-3

Wang, Q., Men, L., Gao, L., Tian, Y. (2017) Effect of grafting and gypsum application on cucumber (Cucumis sativus L.) growth under saline water irrigation. Agricultural Water Management, 188,
79-90. doi:10.1016/j.agwat.2017.04.003

Wang, Y., Gong, X., Liu, W., Kong, L., Si, X., Guo, S., Sun, J. (2020) Gibberellin mediates spermidine-induced salt tolerance and the expression of GT-3b in cucumber. Plant Physiology and Biochemistry,152, 147-156.https://doi. org/10.1016/j.plaphy.2020.04.041

Wen, B., Li, X., Yang, F., Lu, X., Li, X., Yang, F. (2017) Growth and physiology responses of Phragmites australis to combined drought-flooding condition in inland saline-alkaline marsh, Northeast China. Ecological Engineering, 108, 234-239. doi:10.1016/j.ecoleng.2017.08.036

Wu, J., Shu, S., Li, C., Sun, J., Guo, S. (2018) Spermidinemediated hydrogen peroxide signaling enhances the antioxidant capacity of salt-stressed cucumber roots. Plant Physiology and Biochemistry, 128, 152-162. doi:10.1016/j.plaphy.2018.05.002

Wu, X., Shu, S., Wang, Y., Yuan, R., Guo, S. (2019a) Exogenous putrescine alleviates photoinhibition caused by salt stress through cooperation with cyclic electron flow in cucumber. Photosynthesis Research, 141:303-314. doi:10.1007/s11120-01900631-y

Wu, Y., Hu, L., Liao, W., Mujitaba Dawuda, M., Lyu, J., Xie, J., Feng, Z., Calderón-Urrea, A., Yu, J. (2019b) Foliar application of 5-aminolevulinic acid (ALA) alleviates $\mathrm{NaCl}$ stress in cucumber (Cucumis sativus L.) seedlings through the enhancement of ascorbate-glutathione cycle. Scientia Horticulturae, 257, 108761. doi:10.1016/j.scienta.2019.108761

Xiao, X., Cheng, Z., Lv, J., Xie, J., Ma, N., Yu, J. (2019) A green garlic (Allium sativum L.) based intercropping system reduces the strain of continuous mono-cropping in cucumber (Cucumis sativus L.) by adjusting the micro-ecological environment of soil. PeerJ. 2019; 7: e7267. doi: $10.7717 /$ peerj. 7267

Yin, J., Jia, J., Lian, Z., Hu, Y., Guo, J., Huo, H., Jia Guo, J., Huo, H., Zhu, Y., Gong, H. (2019) Silicon enhances the salt tolerance of cucumber through increasing polyamine accumulation and decreasing oxidative damage. Ecotoxicology and Environmental Safety, 169, 8-17. doi:10.1016/j. ecoenv.2018.10.105

Youssef, S. M., Abd Elhady, S. A., Aref, R. M., Riad, G. S. (2018) Salicylic Acid Attenuates the Adverse Effects of Salinity on Growth and Yield and Enhances Peroxidase Isozymes Expression more Competently than Proline and Glycine Betaine in 
Cucumber Plants. Gesunde Pflanzen, 70 (2), 7590. doi:10.1007/s10343-017-0413-9

Yuan, Y., Zhong, M., Du, N., Shu, S., Sun, J., Guo, S. (2019) Putrescine enhances salt tolerance of cucumber seedlings by regulating ion homeostasis. Environmental and Experimental Botany,165, 7082. doi:10.1016/j.envexpbot.2019.05.019

Zarei, M. J., Kazemi, N., Marzban, A. (2019) Life cycle environmental impacts of cucumber and tomato production in open-field and greenhouse. $J$. the Saudi Society of Agricultural Sciences, 18 (3), 249255. doi:10.1016/j.jssas.2017.07.001

Zhang, F., Wang, Y., Liu, C., Chen, F., Ge, H., Tian, F., Yang, T., Ma, K., Zhang, Y. (2019) Trichoderma harzianum mitigates salt stress in cucumber via multiple responses. Ecotoxicology and Environmental Safety, 170, 436-445. doi:10.1016/j. ecoenv. 2018.11.084

Zhang, H., Chen, S., Zhang, Q., Long, Z., Yu, Y., Fang, H. (2020c) Fungicides enhanced the abundance of antibiotic resistance genes in greenhouse soil. Environmental Pollution, 113877. doi:10.1016/j. envpol.2019.113877

Zhang, T., Shi, Z., Zhang, X., Zheng, S., Wang, J., Mo, J. (2020c) Alleviating effects of exogenous melatonin on salt stress in cucumber. Scientia Horticulturae, 262, 109070. doi:10.1016/j.scienta.2019.109070

Zhang, X.-W., Liu, F.-J., Zhai, J., Li, F.-D., Bi, H.G., Ai, X.-Z. (2020a) Auxin acts as a downstream signaling molecule involved in hydrogen sulfideinduced chilling tolerance in cucumber. Planta, 251 (3). doi:10.1007/s00425-020-03362-w

Zhang, Y., Zhuang, W-Y. (2020) Trichoderma brevicrassum strain TC967 with capacities of diminishing cucumber disease caused by Rhizoctonia solani and promoting plant growth, Biological Control, 142, doi: https://doi org/10.1016/j.biocontrol.2019.104151

Zhang, Z., Wu, P., Zhang, W., Yang, Z., Liu, H., Ahammed, G. J., Cui, J. (2020b) Calcium is involved in exogenous $\mathrm{NO}$-induced enhancement of photosynthesis in cucumber (Cucumis sativus L.) seedlings under low temperature. Scientia Horticulturae, 261, 108953. doi:10.1016/j. scienta.2019.108953

Zhao, Y., Mao, X., Zhang, M., Yang, W., Di, H. J., Ma, L., Liu, W., Li, B. (2020) Response of soil microbial communities to continuously monocropped cucumber under greenhouse conditions in a calcareous soil of north China. J. Soils and Sediments, 20, 2446-2459. doi:10.1007/s11368020-02603-5

Zhu, Y., Yin, J., Liang, Y., Liu, J., Jia, J., Huo, H., Wu, Z., Yang, R., Gong, H. (2019) Transcriptomic dynamics provide an insight into the mechanism for silicon-mediated alleviation of salt stress in cucumber plants. Ecotoxicology and Environmental Safety, 174, 245-254. doi:10.1016/j. ecoenv.2019.02.075. 